Katarzyna Ostaszewska

\title{
FOUR FUNDAMENTAL METHODOLOGICAL PROBLEMS OF LANDSCAPE GEOGRAPHY
}

\begin{abstract}
Fundamental methodological problems of geography as a science have been identified by Chojnicki (1999) in the following list: goal of research, separate character of research, expected results, and form of scientific explanation. This article presents methodological standpoints taken be landscape geographers towards the above problems, which proved to be as diverse as in the case of the human geography. The article highlights negative consequences of such state of affairs.
\end{abstract}

Key words: physical geography, geoecology, landscape geography, methodology, explanation.

Landscape geography, also called comprehensive physical geography, geoecology or landscape science, emerged as a separate discipline from physical geography around a century ago. The new discipline is unique in that it investigates connections among the components of nature, analysed by the individual disciplines of physical geography: geomorphology, climatology, hydrology, soil geography, plant geography and so on. The emphasis on the identification of relationships among the investigated components makes landscape geography close to ecology. The affinity of both sciences became visible in particular in the recent three decades, when the term "landscape ecology" became a synonym of a new scientific discipline, joining the achievements of geography and ecology (Richling 1996; Richling, Solon 2002). The comprehensive character of the landscape science is also favourable for its rapprochement to socio-economic geography and to applied disciplines such as spatial planning, urban physiography and sozology.

Similarly to the majority of young sciences, landscape geography focuses on working out and testing new research methods, putting research activity before philosophical reflection. It was only in recent years that scientists directed their attention to the scarcity of discussions devoted to the general methodological foundations of the landscape research and the adverse effects of this situation for the scientific status of this discipline (cf. Pietrzak 1998, Ostaszewska 2002).

Let's explore the most important methodological issues of landscape geography (Chojnicki 1999):

- The issue of the goals of landscape research. 
- The method of justification of its identity as a separate scientific discipline.

- Expected cognitive results.

- Forms of scientific explanation.

The goal of the landscape research is usually formulated as cognitive, that is, as striving to describe, understand and explain reality. Practical goals, external with respect to science, are relegated to the second place. In the methodology of science such approach is called cognitivism (Chojnicki 1999). It is worth emphasising, however, that a different approach is encountered among landscape ecologists, in particular in Anglo-Saxon countries. This approach favours practical goals, to which cognition is subordinated. This approach is called practicism. The described standpoints, although different, are not in such a strong opposition as some Western authors suggest (e.g., Trepl 1996).

The separate character of landscape research as a scientific discipline arouses a much stronger controversy. Among arguments for its separate character are counterparts of all methodological standpoints of geography (cf. Chojnicki 1999). These are:

- Standpoint of subjective separatism that holds that the separate character of landscape research is determined by the way in which researchers conduct their work.

- Standpoint of objective separatism, existing in two variants:

- the so-called substantial variant, emphasising the specific character of the landscape as the object of cognition,

- the so-called methodological variant, emphasising the specific character of the methodology of landscape research.

The standpoint of subjective separatism tends to be accepted by Western authors, representing various directions in contemporary landscape ecology (after Richling 1996). They treat the assumptions of the landscape research in an instrumental way, arising from the philosophy of radical pragmatism.

The standpoint of objective separatism, in particular in its substantial variant, requires stronger methodological assumptions. The stronger of its versions assumes the acceptance of ontological assumptions, which state that the landscape is a real substance (thing, object). This object is usually understood as a complex, hierarchically ordered geosystem, capable of being investigated at its higher (above-component) level. Such standpoint is represented, among others, by Richling and Solon (2002) and Fliedner (1999). A more traditional version of this standpoint assumes that it is not the object itself (the geosystem as a whole) that is the subject of landscape research, but some of its characteristics and its relationships with other objects (e. g., Semmel 1983). In this case the attention of researchers is focused on the effects occurring among selected elements, for instance among individual components of nature or between nature and society. One can also encounter the approach, which holds that the separate character of geographical landscape research is determined above all by the research methods, emphasising the ordering of 
phenomena in space. An example of such approach is the work by Schultz (1988), devoted to the landscape zones of the world.

Chojnicki (1999) writes that substantial separatism in the geosystemic formulation is the most consistent attempt at delimiting of the investigative field of geography. This formulation, however, has not yet been sufficiently specified. A similar situation exists in the landscape geography, in which the notion of the landscape geosystem is still being defined in various ways (cf. Pietrzak 1998, Richling, Solon 2002, Ostaszewska 2002).

As regards the expected cognitive results of landscape geography, two standpoints are emerging. The first, more traditional, is represented by the advocates of the so-called descriptivism, who underscore the high value of the cognitive description which includes gathering, sorting and classifying of the data. The standpoint of descriptivism is best expressed by the idea of regionalisation as a result of landscape research. This idea, which emphases the uniqueness of natural arrangements, keeps returning in landscape geography for years, also in our times (e.g., Przewoźniak 1999).

The other standpoint is called theoretism. While accepting the value of the cognitive description its advocates call for the creation of theories of landscape that would be characterized by generality. The restrictive variant of this standpoint calls for theories of landscape that should include scientific laws - as in the exact natural sciences. The liberal variant calls for theories with general statements, agreeing with facts and making possible the formulation of forecasts. The tendency to work out a theory of landscape is particularly visible among researchers emphasising the physico-geographical origins of the discipline and its ties with other natural sciences.

The notion of the zonality of landscape systems, originating in the $19^{\text {th }}$ century in the works of Dokuchayev and still developed by physical geographers (e.g., Schultz 1988), is an example of a general theory satisfying the demands of the liberal theoretism. In more recent works attempts to create a theory of landscape by means of empirical models construction or of testing theoretical models are undertaken. For their verification quantitative data, which make possible the uniformisation of the level of research of all investigated components, are used. In practice, these are mostly physico-chemical indicators, which may raise suspicions that this approach is reductionist. In the case of landscape geography this approach is, however, instrumental and not programmatic. Analogously, a physician uses the results of X-rays, analyses of body fluids, genetic research and so on, without reducing the whole organism to its components. There is, however, no agreement regarding the need of using this method to creation of a landscape theory. The advocates of the investigation of the chemical or physical characteristics of the landscape are sometimes regarded as representatives of separate disciplines: geochemistry of landscape and geophysics of landscape (Finke 1994, Richling, Solon 2002) and sometimes as representatives of landscape geography utilising a special research methodology (Polynov 1956, Kondracki 1976, Dräyer 1996, Ostaszewska 2002). 
References to the lower level of the organisation of nature favour the explanation of states and behaviours of landscape by means of the laws of exact sciences. The advocates of this form of explanation of landscape phenomena represent the standpoint of the so-called nomological explanationism, that is, of the explanation of events as occurrences of scientific laws (Chojnicki 1999). In landscape geography this standpoint is less radical than, for instance, in hydrology or in dynamical geomorphology. Extranomological explanations, based on comparative studies and typological generalisations, are still valued. Landscape geographers are characterised by a distinct preference for empirical rather than theoretical interests and for inductive rather than deductive approach. This probably follows from the tradition of this discipline, which documents the characteristics of particular places. Another reason may be the fear of being accused of idealisation of the discussion; such accusations have been stated often and not entirely without reason (cf. Finke 1994, Trepl 1996). As Armand wrote bluntly (Armand 1980, p. 9), in our science "many a dogma (...) based not on facts obtained from observations, but on traditional notions, on statements made the by authorities in the field or on incorrect borrowings from other disciplines became established". In this situation it is not surprising that any new "borrowings" are not entirely trusted. This is the case both as regards the laws of exact natural sciences (references to which are treated with suspicions, as attempts to reducing landscape geography to physics or chemistry) and as regards mathematical models (whose use easily leads to accusations of over-generalisation, or idealism, of the discussion). The empirical-inductive approach is chosen in such situations instinctively, as it were, as a traditional method of creation of typological generalisations, tested in many disciplines, also in geography. This approach is also the most often accepted methodological model of our discipline. It does not create favourable conditions for a fast development of the theory of landscape and remains in opposition to the hypothetical-deductive approach, widespread, for instance, in landscape ecology.

Finally it is worth emphasising that the fragmentation and isolation of the individual schools and theoretical-methodological standpoints weakens the position of the geographers among the representatives of other disciplines dealing with landscape research. As a result, some achievements of the geographical landscape theory have remained unnoticed for a long time. As Leser (1992) correctly remarked, the elements of the theory of geosystem, worked out by physical geographers more than half a century ago, became widely known in the landscape theory only in the 1970s, thanks to the research schools founded by ... biologists and ecologists. In this context, a more intense methodological discussion, which Polish geographers entered at the end of the $20^{\text {th }}$ century, seems a necessary stage for the quick completion of the overly long-lasting "young age" of this discipline. As the above discussion shows, the lack of theoretical-methodological interests did not protect the landscape geographers from any of the questions, which in the human geography have been for a long time the subject of scientific discussion. 


\section{REFERENCES}

Armand D.L., 1980, Nauka o krajobrazie [The Science of the Landscape; in Polish], PWN, Warszawa.

Chojnicki S., 1999, Dylematy metodologiczne geografii [Methodological Dilemmas of Geography; in Polish], in: Chojnicki Z., Podstawy metodologiczne i teoretyczne geografii [Methodological and Theoretical Foundations of Geography; in Polish], Bogucki Wyd. Naukowe, Poznań.

Dräyer D., 1996, GIS-gestützte Bodenerosionsmodellierung im Nordwestschweizerischen Jura, Basler Beiträge zur Physiogeographie, Physiogeographica B. 22, Basel.

Finke L., 1994, Landschaftsökologie, Westermann, Braunschweig.

Fliedner D., 1999, Komplexität und Emergenz in Gesellschaft und Natur, Peter Lang, Frankfurt a. Main

Kondracki J., 1976, Podstawy regionalizacji fizykogeograficznej [Foundations of the Physicogeographical Regionalisation; in Polish], PWN, Warszawa.

Leser H., 1992, Geographie und Umwelt-Wissenschaftsverständnis im Wandel? GAIA, 2.

Ostaszewska K., 2002, Geografia krajobrazu. Wybrane zagadnienia metodologiczne [Landscape Geography. Selected Methodological Issues; in Polish], Wyd. Nauk. PWN, Warszawa

Pietrzak M., 1998, Syntezy krajobrazowe. Założenia, problemy, zastosowania [Landscape Syntheses. Assumptions, Problems, Applications; in Polish], Bogucki Wydawnictwo Naukowe, Poznań

Polynov B.B., 1956, Izbrannyye trudy [Selected Works; in Russian], Izd. Akademii Nauk SSSR, Moscow.

Przewoźniak M., 1999, O badaniach struktury przestrzennej środowiska przyrodniczego w polskiej geografii fizycznej [On the Research on the Spatial Structure of the Natural Environment in Physical Geography in Poland; in Polish], in: Domański B., Widacki W. (eds), Geografia polska u progu trzeciego tysiaclecia [Polish Geography at the Dawn of the Third Millennium; in Polish], Inst. Geografii UJ, Kraków.

Richling A., 1996, Ekologia krajobrazu jako dyscyplina jednocząca przyrodników [Landscape Ecology as a Discipline Uniting Natural Scientists; in Polish], Przeglad Geograficzny, LXVIII, 1-2.

Richling A., Solon J., 2002, Ekologia krajobrazu [Landscape Ecology; in Polish], Wyd. Naukowe PWN, Warszawa.

Schultz J., 1988, Die Ökozonen der Erde: die ökologische Gliederung der Geosphäre, Ulmer, Stuttgart.

Semmel A., 1983, Landschaftsnutzung unter geowissenschaftlichen Aspekten in Mitteleuropa, Frankfurter geowiss. Arbeiten, Serie D, Frankfurt a. M.

Tre pl L., 1996, Die Landschaft und die Wissenschaft, in: Konold W. (ed.), NaturlandschaftKulturlandschaft: Die Veränderung der Landschaften nach Nutzbarmachung durch die Menschen, Ecomed, Landsberg

English translation: Matgorzata Mikulska 